\title{
Cytosine arabinoside-metabolizing enzyme genes are underexpressed in children with $M L L$ gene-rearranged acute lymphoblastic leukemia
}

\author{
J.F. Mata ${ }^{1}$, C.A. Scrideli ${ }^{1}$, \\ R.P. Queiroz ${ }^{1}$, B.O. Mori ${ }^{1}$, \\ M. Emerenciano ${ }^{2}$, \\ M.S. Pombo-de-Oliveira ${ }^{2}$ \\ and L.G. Tone ${ }^{1}$
}

\author{
${ }^{1}$ Departamento de Pediatria e Puericultura, Faculdade de Medicina de Ribeirão Preto, \\ Universidade de São Paulo, Ribeirão Preto, SP, Brasil \\ ${ }^{2}$ Instituto Nacional do Câncer, Rio de Janeiro, RJ, Brasil
}

\section{Correspondence \\ C.A. Scrideli \\ Departamento de Pediatria e \\ Puericultura \\ FMRP, USP \\ Av. Bandeirantes, 3900 \\ 14049-900 Ribeirão Preto, SP \\ Brasil \\ Fax: +55-16-3602-2700 \\ E-mail: cascrideli@hcrp.fmrp.usp.br \\ Research supported by FAEPA, FAPESP and CNPq. M. Emerenciano and M.S. Pombo-de-Oliveira are supported by the INCA/FAF-Swiss Bridge Fund (No. 2301504).}

Received February 21, 2006 Accepted August 18, 2006

\begin{abstract}
Infant acute lymphoblastic leukemia (IALL) is characterized by mixed lineage leukemia $(M L L)$ gene rearrangements, unique gene expression profiles, poor prognosis, and drug resistance. One exception is cytosine arabinoside (Ara-C) to which IALL cells seem to be more sensitive. We quantified mRNA expression of Ara-C key enzymes in leukemic lymphoblasts from 64 Brazilian ALL children, 15 of them presenting $M L L$ gene rearrangement, and correlated it with clinical and biological features. The diagnosis was based on morphological criteria and immunophenotyping using monoclonal antibodies. $M L L$ gene rearrangements were detected by conventional cytogenetic analysis, RT-PCR and/or fluorescence in situ hybridization. The DCK and HENTI expression levels were determined by real-time quantitative PCR using SYBR Green I. Relative quantification was made by the standard curve method. The results were analyzed by Mann-Whitney and Fisher exact tests. A P value of $\leq 0.05$ was considered to be statistically significant. DCK and HENTI expression levels were significantly lower in children with $M L L$ gene-rearranged ALL compared to children with $M L L$ germ line ALL ( $\mathrm{P}=0.0003$ and 0.03, respectively). Our results differ from previous ones concerning HENTI mRNA expression that observed a higher expression level in $M L L$ gene-rearranged leukemias. In conclusion, the expression of the genes related to Ara-C metabolism was lower in $M L L$-positive children in the sample studied, suggesting the presence of population differences in the expression profile of these genes especially for HENTI.
\end{abstract}

Key words

- Cytosine arabinoside

- Acute lymphoblastic leukemia

- Infant

- Mixed lineage leukemia

gene rearrangement

- Gene expression

\section{Introduction}

There is evidence that specific leukemic subgroups may have distinct etiologies, and that molecular abnormalities associated with particular subgroups may be linked to spe- cific causal mechanisms. Infant acute lymphoblastic leukemias (IALLs) display unique biological features (e.g., nearly $80 \%$ of infants with leukemia have a leukemic cell abnormality involving the mixed lineage leukemia gene, $M L L$ ) and clinical features (e.g., 
increased rates of treatment failure in infants compared to older children) that provide investigative models and important insights for the study of leukemogenesis (1).

Previously reported gene expression profiles have shown that ALLs possessing a rearranged $M L L$ gene have a highly uniform and unique pattern that clearly distinguishes them from other ALL subtypes (2,3).

The optimum treatment for patients with $M L L$ gene rearrangements remains to be identified. The very poor outcome of treatment for these patients, especially those diagnosed during infancy, has led to the recommendation of allogeneic hemopoietic stem-cell transplantation (4). A better understanding of the pharmacokinetics and chemosensitivity of IALLs may contribute to improving treatment and prognosis. Pieters et al. (5) showed in in vitro experiments that leukemic cells from infants with ALL are more resistant to prednisone and L-asparaginase and more sensitive to cytosine arabinoside (Ara-C) than cells from older children with ALL.

Ara-C is a nucleoside analogue which mimics physiological nucleoside uptake and metabolism resulting in cell death. Ara-C is taken up by cells mainly via the human equilibrate nucleoside transporter 1 . Inside the cell, deoxycytidine kinase (dCK) primarily phosphorylates Ara-C into arabinoside monophosphate (Ara-CMP) and Ara-CMP is subsequently phosphorylated into its active cytotoxic form cytarabine triphosphate (Ara-CTP) until incorporation into DNA. For a standard-dose Ara-C, membrane transport capacity could be the rate-limiting step, but with high-dose Ara-C the activity of dCK may limit Ara-CTP formation (6).

To determine the clinical significance of mRNA expression of Ara-C-metabolizing enzymes in childhood ALL we quantified mRNA expression in leukemic blasts from 64 Brazilian children diagnosed with ALL by the real-time quantitative polymerase chain reaction (RQ-PCR). We also attempted to correlate its expression levels with some relevant clinical and biological features such as age, white blood cell (WBC) count at diagnosis, common ALL antigen (CALLA) expression, 11q23/MLL aberrations, and minimal residual disease level at day 28 of induction therapy.

\section{Material and Methods}

\section{Patients}

Written informed consent was obtained from the parents of all patients (including the ones with normal bone marrow, BM) at the time of enrollment, and all aspects of this investigation were approved by the Ethics Committees of the institutions involved in the study.

We analyzed BM samples from 44 consecutive untreated children with ALL from the University Hospital, Medical School of Ribeirão Preto, University of São Paulo. The samples were compared to those from 20 children aged less than 24 months ( 7 of them less than 12 months old) from the Brazilian Infant Leukemia Study Group coordinated by Instituto Nacional do Câncer, Rio de Janeiro, RJ, Brazil, between January 1998 and March 2004. Ten BM samples obtained from children without hematological disease, 5 children who underwent cardiac surgery for correction of congenital cardiopathies and 5 children who were BM donors, were used to determine normal BM expression. Only patients with normal hematological counts who exhibited no evidence of infections, genetic diseases, autoimmune disorders, renal, or hepatic dysfunctions were considered to be eligible. All samples contained at least $90 \%$ leukemic cells on light microscopy, and were morphologically classified as ALL according to French American British criteria (7) and immunophenotypically determined using a broad panel of monoclonal antibodies following EGIL classification (8). Samples were subjected to conventional cytogenetic analysis for the 
presence of $M L L$ gene aberrations, RT-PCR (standard and nested) for the presence of an MLL/AF4 fusion transcript [t(4;11) (q21; q23)] and tested by fluorescence in situ hybridization using a VYSIS LSI MLL probe (9). Gene fusion transcripts were detected with the standardized primer sets proposed by the BIOMED-1 Concerted Action (10). Detection of minimal residual disease (MRD) at day 28 of induction therapy was performed by PCR using consensus primers for the detection of a clonal population for TCR $\gamma$, IgH and TCR $\delta$. This method can detect one leukemic cell in $10^{2}-10^{3}$ normal cells $(11,12)$.

\section{RNA extraction and cDNA synthesis}

Total cellular RNA was extracted using the TRIzol LS Reagent (Invitrogen, Carlsbad, CA, USA) according to the manufacturer's protocol. An additional phenol-chloroform extraction was performed and isopropanol precipitation occurred at $-20^{\circ} \mathrm{C}$. The RNA quality was examined by gel electrophoresis. Following a denaturation step of $10 \mathrm{~min}$ at $70^{\circ} \mathrm{C}$, RNA was reverse transcribed to single-stranded cDNA using a mix of random primers $(3 \mu \mathrm{g} / \mu \mathrm{L}$; Invitrogen). The reverse transcription reaction was performed in a total volume of $25 \mu \mathrm{L}$ containing $0.2 \mathrm{mM}$ of each dNTP (Invitrogen), 200 U Moloney murine leukemia virus reverse transcriptase (Invitrogen), and 25 U RNase-OUT (Invitrogen) at $37^{\circ} \mathrm{C}$ for $20 \mathrm{~min}, 70^{\circ} \mathrm{C}$ for $10 \mathrm{~min}$, and $37^{\circ} \mathrm{C}$ for $60 \mathrm{~min}$.

\section{Quantitative real-time polymerase chain reactions}

The mRNA expression levels of $D C K$, $H E N T 1$, and an endogenous housekeeping gene encoding for beta-glucuronidase $(G U S B)$ as a reference were quantified using real-time PCR analysis (SYBR green I dye) on a Gene Amp ${ }^{\circledR} 5700$ Sequence Detection System (PE Applied Biosystems, Foster City, CA, USA) (13). Amplification of specific
PCR products was detected using the SYBR Green PCR Master Mix (Applied Biosystems). All primers employed were cDNA specific and were purchased from Invitrogen (São Paulo, SP, Brazil). DCK and HENT1 designed primers were: a) $D C K$ forward primer, TGCAGGGAAGTCAACATT; $D C K$ reverse primer, TCCCACCATTTTTCTGAG; b) HENTl forward primer, TGTTTCCAGC CGTGACT; HENT1 reverse primer, CAGG CCACATGAATACAG and GUSB primer were chosen after the evaluation performed by the Europe Against Cancer program (14); c) GUSB forward primer, GAAAATATGT GGTTGGAGAGCTCATT; GUSB reverse primer, CCGAGTGAAGATCCCCTTTTTA. The RQ-PCR was performed in duplicate in a total reaction volume of $20 \mu \mathrm{L}$ containing $10 \mu \mathrm{L}$ SYBR Green PCR Master Mix, 15 $\mu \mathrm{M}$ forward and reverse primers, $3.5 \mu \mathrm{L}$ $\mathrm{dH}_{2} \mathrm{O}$, and 40 ng cDNA from each patient as a template. Samples were heated for $10 \mathrm{~min}$ at $95^{\circ} \mathrm{C}$ and amplified for 50 cycles of $15 \mathrm{~s}$ at $95^{\circ} \mathrm{C}$ and of $60 \mathrm{~s}$ at $60^{\circ} \mathrm{C}$. Blank and positive controls (calibrators) were run in parallel to determine amplification efficiency within each experiment. Each run was completed with a melting curve analysis to confirm the specificity of amplification and lack of primer dimers. Quantification was performed using the standard curve method. A serial dilution in $\mathrm{dH}_{2} \mathrm{O}$ of cDNA derived from a cell line RNA pool (K562-Lucena) used as calibrator was amplified to construct standard curves for both target and control genes. The slopes of the standard curves ranged from -3.2 to -3.9. For each patient sample, the amount of target and control gene was determined from the appropriate standard curve. The target amount was subsequently divided by the control gene amount to obtain a normalized target value and calibrated by the standard RNA sample (15).

\section{Statistical analysis}

Statistical analysis was performed using 
the SPSS 10 Software (SPSS Inc., Chicago, IL, USA). Correlation between $D C K$ and HENTI expression was tested in association with some variables such as age (younger than 24 months versus older than 24 months), WBC count at diagnosis (less than $50 \times 10^{9}$ / $\mathrm{L}$ versus more than $\left.50 \times 10^{9} / \mathrm{L}\right)$, CALLA surface antigen expression at diagnosis (positive versus negative), $M L L$ translocations and MRD at day 28 (positive versus negative) of induction therapy based on the non-

Table 1. Patient characteristics.

\begin{tabular}{lcc}
\hline & $\begin{array}{c}\text { Infants } \\
(\mathrm{N}=20)\end{array}$ & $\begin{array}{c}\text { Older children } \\
(\mathrm{N}=44)\end{array}$ \\
\hline Sex (male:female ratio) & $\begin{array}{c}1.5: 1 \\
\text { Age (median) }\end{array}$ & $\begin{array}{c}1.3: 1 \\
\text { CALLA positive }\end{array}$ \\
WBC count $\geq 50 \times 10^{9} / \mathrm{L}$ & $40 \%$ & 65 months \\
MLL rearranged & $50 \%$ & $30 \%$ \\
Survival status & $50 \%$ & $7 \%$ \\
$\quad$ Complete clinical remission & & \\
Dead/relapse & $40 \%$ & $77 \%$ \\
Unknown & $55 \%$ & $16 \%$ \\
\end{tabular}

aChildren younger than 24 months of age; CALLA $=$ common acute lymphoblastic leukemia antigen; $\mathrm{WBC}=$ white blood cell count; $\mathrm{MML}=$ mixed lineage leukemia gene.

Table 2. DCK and HENT1 gene expression by 64 patients with acute lymphoblastic leukemia.

\begin{tabular}{lll}
\hline Patient characteristics & DCK expression & HENT1 expression \\
\hline Normal bone marrow & $1.5800(0.76596-3.8305)$ & $1.7852(0.65094-3.59462)$ \\
ALL bone marrow & $0.2306(0.00008-1.7229)$ & $0.0798(0.000001-3.16779)$ \\
MLL rearranged & $0.0224(0.00009-0.3047)$ & $0.0231(0.000002-0.53414)$ \\
MLL germ line & $0.3883(0.00008-1.7229)$ & $0.2012(0.000001-3.16779)$ \\
Age under 24 months & $0.0450(0.00008-1.7229)$ & $0.0131(0.000001-0.9176)$ \\
24 months and older & $0.3577(0.00035-1.6592)$ & $0.1200(0.00008-3.16779)$ \\
WBC $<50.000 / \mathrm{mm}^{3}$ & $0.3404(0.00032-1.7229)$ & $0.0481(0.000002-3.16779)$ \\
WBC $\geq 50.000 / \mathrm{mm}^{3}$ & $0.1323(0.00008-1.55477)$ & $0.1057(0.000001-0.94910)$ \\
CALLA positive & $0.3659(0.00035-1.7229)$ & $0.1057(0.000012-2.11626)$ \\
CALLA negative & $0.1197(0.00008-1.28326)$ & $0.0221(0.000001-3.16779)$ \\
TEL/AML1 positive & $0.3457(0.02368-1.5547)$ & $0.1440(0.02107-1.39629)$ \\
TEL/AML1 negative & $0.3577(0.00008-1.7229)$ & $0.1727(0.000001-3.16779)$ \\
MRD d28 positive & $0.2051(0.11977-1.65924)$ & $0.6765(0.02107-3.16779)$ \\
MRD d28 negative & $0.4549(0.02744-1.55477)$ & $0.4535(0.00148-1.94569)$
\end{tabular}

Data are reported as median values with range in parentheses. $A L L=$ acute lymphoblastic leukemia; $M M L=$ mixed lineage leukemia gene; $\mathrm{WBC}=$ white blood cell count; CALLA = common ALL antigen; $M R D=$ minimal residual disease. parametric Mann-Whitney test and Fisher exact test. In the Fisher exact test analysis, these variables were evaluated by considering the median of the values detected for $D C K$ and HENT1 gene expressions. A $\mathrm{P}$ value of $\leq 0.05$ was considered to be statistically significant.

\section{Results}

The demographic and laboratory characteristics of the children included in this study are shown in Table 1 . There were 37 boys and 27 girls aged 0-204 months (median 41 months), 56 had B-lineage ALL (42 $C A L L A+), 7$ had T-lineage ALL, and 1 had ALL that was not immunophenotyped. Abnormalities involving 11q23/MLL were detected in 15 patients, $4 / 7(57 \%)$ of them less than 12 months old, $8 / 13(61 \%)$ between 12 24 months, and 3/44 (7\%) more than 24 months old, and $11 / 15$ presented the CALLAimmunophenotype. All children were classified and treated according to the guidelines of the Brazilian Cooperative Group for the Treatment of Childhood Leukemia (GBTLI93 and GBTLI-99): 39 were classified as being at high risk of relapse and 25 as being at standard risk. Ten children without hematological disease for whom BM aspirates were used to verify standard $D C K$ and HENT1 expression were 3 boys and 7 girls aged 0-144 months (median 20 months).

The expression of both the $D C K$ and HENT1 genes in the BM of children with no hematological disease was significantly higher than that observed in children with ALL $(\mathrm{P}<0.001$ for both genes; Figure 1). Median values of gene expression were 1.58 vs 0.23 for $D C K$ and 1.78 vs 0.07 for HENTI (Table 2). These differences, although statistically significant, should be considered with caution due to the heterogeneity of BM and the fact that BM cannot be considered the appropriate normal counterpart of leukemic cells.

The levels of $D C K$ expression were lower 
in ALL MLL-positive children in both analyses (median 0.02 vs $0.38 ; \mathrm{P}=0.0003$ and 0.002 by the nonparametric Mann-Whitney test and by the Fisher exact test, respectively), and HENTI levels were also lower in $M L L$-positive children (median 0.02 vs 0.20 ; $\mathrm{P}=0.03$ ) by the nonparametric Mann-Whitney test. Also, no significant correlation was found by the Fisher exact test $(\mathrm{P}=0.24)$ compared to children with $M L L$ germ line ALL (Figure 2).

The 20 children younger than 24 months with ALL had lower levels of $D C K$ expression $(\mathrm{P}=0.005)$ and borderline HENT1 levels $(\mathrm{P}=0.06$ and 0.09 by the nonparametric Mann-Whitney test and the Fisher exact test, respectively) compared to older children. The levels of DCK and HENTI expression were not compared in children younger than 12 months due to the small number of cases.

Only by the Fisher exact test was it possible to determine a correlation between increased $D C K$ expression and the presence of the CALLA ( $\mathrm{P}=0.03)$, whereas this association was not detected by the nonparametric Mann-Whitney test $(\mathrm{P}=0.07)$ or by any of the analyses carried out on the HENT1 gene.

For the remaining variables analyzed (initial WBC count and MRD at day 28 of induction) no significant correlation was detected for either the DCK or HENT1 gene in any analysis.

\section{Discussion}

Characterized by $M L L$ gene rearrangements, unique gene expression profiles, and a poor prognosis, infant ALL is usually considered to be a separate subgroup of childhood ALL $(1,16,17)$. Prognostic features play a critical role in directing therapy for ALL, and as ALL treatment has become more successful, most efforts have focused on identifying patients at a higher risk of treatment failure that can be targeted with more aggressive or differentiated types of therapy. The identification of genes associated

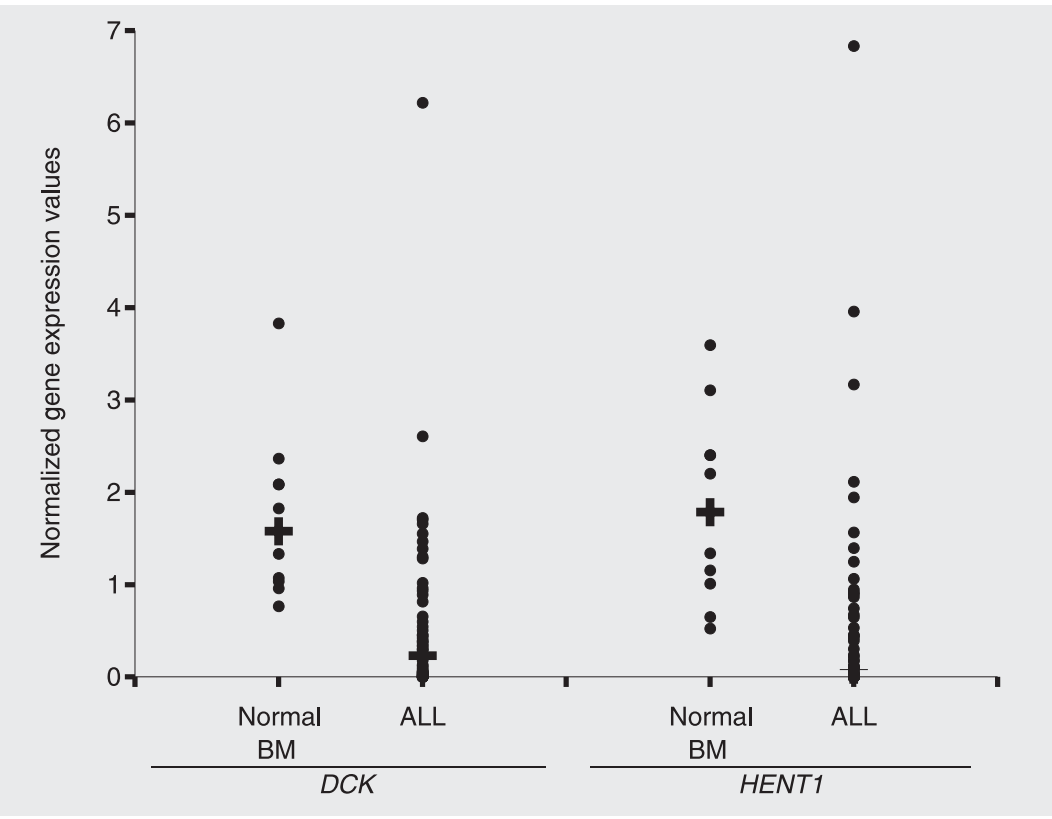

Figure 1. DCK and HENT1 mRNA expression in normal and in acute lymphoblastic leukemia (ALL) bone marrow (BM). Deoxycytidine kinase (DCK; left graph) and human equilibrative nucleoside transporter 1 (HENT1; right graph) mRNA expression levels in bone marrow of children without hematological disease (first columns) and in ALL bone marrow (second columns; $\mathrm{P}<0.001$ for both the DCK and HENT1 genes, according to the Mann-Whitney test). The horizontal lines of the pluses indicate the median values (1.58 vs 0.23 for $D C K$ and 1.78 vs 0.07 for HENT1) and the filled circles indicate values for individual patients.

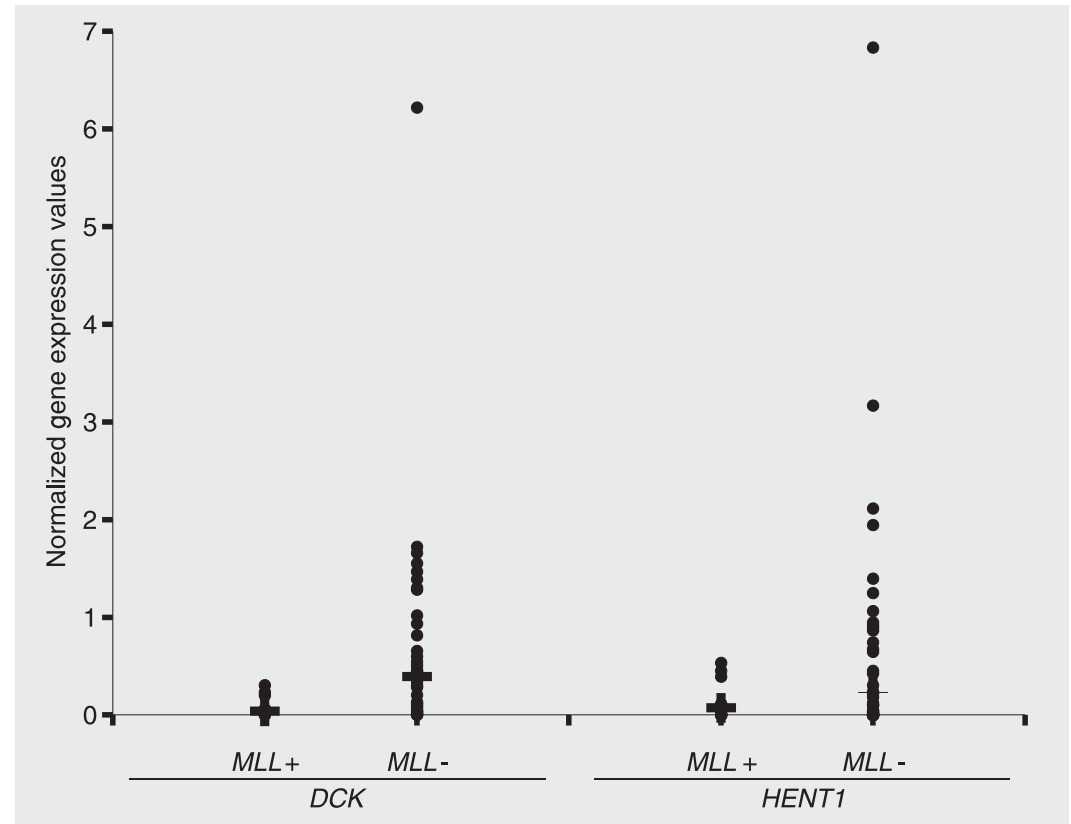

Figure 2. DCK and HENT1 mRNA expression in children with acute lymphoblastic leukemia (ALL) with MLL gene-rearranged and MLL germ line. DCK (left graph) and HENT1 (right graph) mRNA expression in ALL children with $M L L$ gene rearranged and $M L L$ germ line (median 0.02 vs $0.38 ; \mathrm{P}=0.0003$ for $D C K$ and median 0.02 vs $0.20 ; \mathrm{P}=0.03$ for HENT1, according to the Mann-Whitney test). The horizontal lines of the pluses indicate the median values and the filled circles indicate values for individual patients. 
with the process of chemotherapeutical drug metabolism is suggested as an important tool to predict ALL survival (18).

Both genes showed higher expression in $\mathrm{BM}$ of children with no hematological disease compared to children with ALL with median values of gene expression of 1.58 vs 0.23 for $D C K$ and 1.78 vs 0.07 for HENT1. Although a similar pattern of expression has been described for normal BM from different lineages and maturation subpopulations and for BM from children with ALL, some genes have been shown to be preferentially expressed by the leukemic cells, suggesting an ectopic activation of these genes and consequently a specific regulatory mechanism of the disease (19). Since in the present study we did not analyze normal BM aspirates from different lineages and maturation subpopulations, these results should be considered with caution.

Previously reported results (20) have revealed that infants with ALL express significantly less $D C K$ and more HENTI mRNA compared to older children. The same differences concerning DCK and HENTI expression were observed by microarray technology between $M L L$ gene rearranged and $M L L$ germ line cases (all ages) by the same group. A proper infant subgroup comparison could not be performed due to the small number of children less than 12 months of age enrolled in the present study. The different pattern of $H E N T 1$ expression verified in $M L L$ generearranged cases in the present study may be explained by factors such as the ethnic diversity of Brazilian children, which, however, would need further investigation to be confirmed. As a limitation of a retrospective study, there were no suitable samples available for cytotoxicity assays and/or for measuring Ara-CTP accumulation in the blasts to correlate in vitro Ara-C sensitivities to HENTI and DCK mRNA expression. In addition, there are some methodological differences between the two studies to be considered such as technology used (microarray versus SYBR Green RQ-PCR in the $M L L$ gene-rearranged analysis) and the internal reference gene. In the present study, the $G U S B$ gene was used as an internal reference gene instead of the GAPDH gene. Some publications agree with the finding that $G A P D H$ expression varies considerably and consequently may be an unsuitable reference for RNA transcription analysis $(14,21)$.

The present results on $D C K$ expression agree with those reported by Stam et al. (20). Previous reports indicated that the blast cells of infants may be more sensitive to Ara-C (5). These data suggest that $D C K$ is not a rate-limiting factor in Ara-C metabolism in infant ALL cells. Another possibility, which was also raised by these investigators, could be that $D C K$ is post-transcriptionally regulated and that, despite the lower mRNA expression, the amount of protein or the activity of the enzyme in infant ALL cells is comparable to, or even higher than in cells from older children with ALL (20).

Mansson et al. (22) compared DCK expression in cell lines and in samples from leukemia patients measured by RQ-PCR and semi-quantitative RT-PCR. Enzyme activity was measured by a radioactive substrate-based technique and Western blot was used to measure the amount of dCK protein. They observed that $D C K$ mRNA levels were in agreement with the activity of the enzyme. This finding suggests that mRNA expression is related to the expression of the protein and the activity of Ara-C-metabolizing enzymes.

The expression of the genes related to Ara-C metabolism was lower in $M L L$-positive children in the sample studied, indicating the pharmacokinetics and biological diversity of ALL, especially in $M L L$-positive children. Further improvement in the outcome of these patients will require new therapies targeted at the specific genetic lesions of the leukemic cells.

\section{Acknowledgments}

The authors wish to thank all the mem- 
bers of the Brazilian Infant Leukemia Study Group and the staff of Instituto Nacional do

Câncer that provided the laboratory results included in this study. We also thank Professor Marco Antônio Zago for sharing laboratory facilities.

\section{References}

1. Biondi A, Cimino G, Pieters R, Pui $\mathrm{CH}$. Biological and therapeutic aspects of infant leukemia. Blood 2000; 96: 24-33.

2. Armstrong SA, Staunton JE, Silverman LB, Pieters R, den Boer ML, Minden MD, et al. MLL translocations specify a distinct gene expression profile that distinguishes a unique leukemia. Nat Genet 2002; 30: 41-47.

3. Yeoh EJ, Ross ME, Shurtleff SA, Williams WK, Patel D, Mahfouz R, et al. Classification, subtype discovery, and prediction of outcome in pediatric acute lymphoblastic leukemia by gene expression profiling. Cancer Cell 2002; 1: 133-143.

4. Pui CH, Gaynon PS, Boyett JM, Chessells JM, Baruchel A, Kamps $\mathrm{W}$, et al. Outcome of treatment in childhood acute lymphoblastic leukaemia with rearrangements of the 11 q23 chromosomal region. Lancet 2002; 359: 1909-1915.

5. Pieters $R$, den Boer ML, Durian M, Janka G, Schmiegelow K, Kaspers GJ, et al. Relation between age, immunophenotype and in vitro drug resistance in 395 children with acute lymphoblastic leukemia - implications for treatment of infants. Leukemia 1998; 12: 13441348.

6. Galmarini CM, Mackey JR, Dumontet C. Nucleoside analogues: mechanisms of drug resistance and reversal strategies. Leukemia 2001; 15: 875-890.

7. Bennett JM, Cato vsky D, Daniel MT, Flandrin G, Galton DA, Gralnick $\mathrm{HR}$, et al. The morphological classification of acute lymphoblastic leukaemia: concordance among observers and clinical correlations. Br J Haematol 1981; 47: 553-561.

8. Bene MC, Castoldi G, Knapp W, Ludwig WD, Matutes E, Orfao A, et al. Proposals for the immunological classification of acute leukemias. European Group for the Immunological Characterization of Leukemias (EGIL). Leukemia 1995; 9: 1783-1786.

9. Macrini CM, Pombo-de-Oliveira MS, Ford AM, Alves G. MLL AThook sequence is strongly conserved in infant acute leukemia with or without MLL gene rearrangement. Leukemia 2003; 17: 14321433.

10. van Dongen JJ, Maclntyre EA, Gabert JA, Delabesse E, Rossi V, Saglio G, et al. Standardized RT-PCR analysis of fusion gene transcripts from chromosome aberrations in acute leukemia for detection of minimal residual disease. Report of the BIOMED-1 Concerted Action: investigation of minimal residual disease in acute leukemia. Leukemia 1999; 13: 1901-1928.

11. Scrideli CA, Kashima S, Cipolloti R, Defavery R, Bernardes JE, Tone LG. Minimal residual disease in Brazilian children with acute lymphoid leukemia: comparison of three detection methods by PCR.
Leuk Res 2002; 26: 431-438.

12. Scrideli CA, Queiroz RG, Bernardes JE, Valera ET, Tone LG. PCR detection of clonal $\mathrm{IgH}$ and TCR gene rearrangements at the end of induction as a non-remission criterion in children with ALL: comparison with standard morphologic analysis and risk group classification. Med Pediatr Oncol 2003; 41: 10-16.

13. Gibson UE, Heid CA, Williams PM. A novel method for real time quantitative RT-PCR. Genome Res 1996; 6: 995-1001.

14. Beillard E, Pallisgaard N, van der Velden V, Bi W, Dee R, van der Schoot $\mathrm{E}$, et al. Evaluation of candidate control genes for diagnosis and residual disease detection in leukemic patients using real-time quantitative reverse-transcriptase polymerase chain reaction (RQPCR) - a Europe against cancer program. Leukemia 2003; 17: 24742486.

15. Scrideli CA, Cazzaniga G, Fazio G, Pirola L, Callegaro A, Bassan R, et al. Gene expression profile unravels significant differences between childhood and adult $\mathrm{Ph}+$ acute lymphoblastic leukemia. Leukemia 2003; 17: 2234-2237.

16. Rubnitz JE, Pui $\mathrm{CH}$. Recent advances in the treatment and understanding of childhood acute lymphoblastic leukaemia. Cancer Treat Rev 2003; 29: 31-44.

17. Friedmann AM, Weinstein HJ. The role of prognostic features in the treatment of childhood acute lymphoblastic leukemia. Oncologist 2000; 5: 321-328.

18. Kaspers GJ, Pieters R, Van Zantwijk $\mathrm{CH}$, van Wering ER, Veerman AJ. Clinical and cell biological features related to cellular drug resistance of childhood acute lymphoblastic leukemia cells. Leuk Lymphoma 1995; 19: 407-416.

19. Andersson A, Olofsson T, Lindgren D, Nilsson B, Ritz C, Eden P, et al. Molecular signatures in childhood acute leukemia and their correlations to expression patterns in normal hematopoietic subpopulations. Proc Natl Acad Sci U S A 2005; 102: 19069-19074.

20. Stam RW, den Boer ML, Meijerink JP, Ebus ME, Peters GJ, Noordhuis $\mathrm{P}$, et al. Differential mRNA expression of Ara-C-metabolizing enzymes explains Ara-C sensitivity in MLL gene-rearranged infant acute lymphoblastic leukemia. Blood 2003; 101: 1270-1276.

21. Lion T. Current recommendations for positive controls in RT-PCR assays. Leukemia 2001; 15: 1033-1037.

22. Mansson E, Liliemark E, Soderhall S, Gustafsson G, Eriksson S, Albertioni $F$. Real-time quantitative PCR assays for deoxycytidine kinase, deoxyguanosine kinase and 5'-nucleotidase mRNA measurement in cell lines and in patients with leukemia. Leukemia 2002; 16: 386-392. 